\title{
Abul A'la Mawdudi's concept of Hakimiyya and its critical assessment in Islamic legal-political thought
}

\section{V.Pugachev}

Leningrad Regional Division of the North-Western Main Branch of the Central Bank of Russian Federation, 4, Shafirovsky prospect, Saint Petersburg, 195273, Russian Federation

For citation: Pugachev, Valerii V. 2018. "Abul A'la Mawdudi's concept of Hakimiyya and its critical assessment in Islamic legal-political thought". Vestnik of Saint Petersburg University. Law 2: 230-241. https://doi.org/10.21638/11701/spbu14.2018.208

The article analyzes the legal-political aspects of the concept of hakimiyya ("divine domination") devised by the Indo-Pakistani theologian Abul A'la Mawdudi (1903-1979). The author asserts that the doctrine of hakimiyya is based upon the recognition that Allah is the sole subject empowered to provide legislation to the Muslim community directly (the principle of "legal domination") and indirectly (the principle of "political domination").The doctrine of hakimiyya acquires its political shape as the Islamic state (caliphate), wherein the Islamic community is entrusted with a limited right to legislation by means of agency (wikala). Special emphasis is laid on examination into the critical appraisal of the hakimiyya doctrinals in the modern Islamic legal science. The article explores the objections raised against the hakimiyya theory by the Indo-Pakistani religious scholars, including Abul Hasan Nadwi and Wahid al-Din Khan, as well as by a number of modern Arabic legal theorists, such as Hasan alHudaybi, Muhammad 'Imara, Muhammad Sayyid al-Ashmawi, Haydar Ibrahim 'Ali a.o. The author concludes that the concept of hakimiyya underlies Mawdudi's doctrine of the sources of law and serves as the basis for his theory of the Islamic state, as well as for his concept of the "renewal of faith" through Islamic revolution.

Keywords: hakimiyya, legal domination, political domination, caliphate, din, Islamic state.

1. Introduction. Abul Ala Mawdudi (further referred to as Mawdudi) has long been considered one of the most influential theorists of Islamic law of the twentieth century. Mawdudi's legal-political doctrine has exerted considerable influence on the current state of the Islamic socio-political thought, with its fundamentals remaining at the center of acute scientific debates in Islamic academia. Of all the various theories introduced by Mawdudi into the Islamic legal thought, it is the doctrine of "divine domination" (hakimiyya ilahiyya) that deserves the most special attention. So far the conceptual foundations of hakimiyya have not been subject to close examination on the part of the Russian researchers in the field of Islamic legal studies. Yet, notwithstanding the fact that the doctrine of hakimiyya was developed in the 1930s, it continues to remain a cornerstone of multiple Islamic political theories, such as Qutbism, "Islamic quietism", and numerous other forms of contemporary Islamic fundamentalism. The present article aims at analyzing the essential features of hakimiyya - the theory which, this author believes, constitutes the most important innovation in Mawdudi's entire intellectual output. After discussing the fundamentals of hakimiyya, special emphasis will be laid on the academic debates that have

(C) Санкт-Петербургский государственный университет, 2018 
been taking place among the Islamic legal scholars about the extent to which this concept corresponds to the basic tenets of Islamic faith and law.

2. Main text. At the core of the theory of hakimiyya lies the assumption that Islam, unlike other world religions, should not be regarded as a mere aggregate comprising diverse theological concepts and ritual practices, but rather that it should be looked upon as, what Mawdudi liked to call it, a "political system" (nizam siyasi). In his seminal lecture delivered in Lahore in 1939 he stated the following: "First, we should clearly understand and always be sensible of the fact that Islam is not just a huddle of unrelated theories and various ways of conduct. It is rather a perfect, comprehensive system resting on a set of rational, thoroughly formulated principles. This system is logically connected to these principles from its important fundamentals up to minor unessential details" (al-Mawdudi $1967,7)$. It is thus distinctive of the "political system" of Islam that it is rooted in axiomatical concepts derived directly from the Qur'anic revelation rather than from the secondary (also known as "rational") sources of Islamic law.

The priority role of the Qur'an in formulating the basic principles of the "political system" of Islam manifests itself precisely in Mawdudi's negative attitude towards the classical exegetic literature. Mawdudi believed that the genuine meanings of all the most crucial political terms of the Qur'an had historically been undergoing a gradual, although hardly noticeable, process of transformation, up until the point at which they had begun to denote only narrow and quite indefinite notions. This development eventually resulted in a situation where in the later dictionaries and commentaries the terms of the original Quranic vocabulary began to be interpreted solely according to their then-contemporary meanings. In addition, Mawdudi tended to think of the classical era legists and theologians as unable to differentiate between the absolute atemporal principles of Islam and their particular spatially and temporarily determined manifestations. From his standpoint, any attempts at interpreting the Qur'anic revelation exclusively on the basis of one's understanding of the needs of the moment would be doomed to failure from the start.

Inasmuch as Islam embodies the idea of freedom of will, it is only by means of independent and unmediated study that a man can understand the true implications of the Quranic revelation. "Man has been endowed with reason and intellect. He has the power to think and form judgments, to choose and reject, and to adopt and spurn. He is free to adopt whatever course of life he chooses. He can embrace any faith, adopt any way of life and formulate his living according to whatever ideologies he likes... He has been bestowed with free will and can chalk out his own course of behavior" (Maududi 1960b, 4). Since man exercises unrestricted free will, it is natural for the Supreme Lawgiver to confine himself to defining only the most imperative principles of Islam, making room for a man to act independently beyond the restrictions imposed upon him. “The Qur'an, to put it succinctly, is a Book of broad general principles rather than of legal minutiae. The Book's main aim is to expound, clearly and adequately, the intellectual and moral foundations of the Islamic programme for life... Its method of guidance for practical Islamic life does not consist of laying down minutely detailed laws and regulations. It prefers to outline the basic framework for each aspect of human activity and to lay down certain guidelines within which man can order his life in keeping with the Will of God" (Mawdudi 1988, 28).

The ideological core of the "political system" of Islam is made up of the so-called "four Quranic terms", which may be deduced directly from the text of the revelation. These terms include 1) rabb ("Master", or "Lord"); 2) ilah ("deity"), and its synonym ma'bud ("an 
object of worship"); 3) 'ibada ("worship"); 4) din ("faith", "religion"). Mawdudi reckoned that whosoever made more than a perfunctory inquiry into the teachings of the Qur'an would soon realize that its entire contents revolved around these four terms only (alMawdudi 1971, 7), and that for the Islamic ideology to be comprehended properly it was essential to fully grasp their respective meanings. It is therefore noteworthy that, in the words of J.-P. Hartung, "although Mawdudi's first two terms refer to the Quranic concept of God, the fundamental doctrine of tawhid seems to have played only an implicit role [in his theory. - P. V.]" (Hartung 2014, 91). Having excluded tawhid, which he defined as faith in the unity of Allah in its broadest sense ${ }^{1}$, from the fundamental political terms of the Quran, he nevertheless claimed that failure to comprehend the true implications of tawhid would amount to one's inability to tell it from shirk.

The word $r a b b$ is supposed to convey the active aspect of the divinity of Allah (rububiyya), which manifests itself in the upbringing of man, instilling in him the fervor of piousness, and, last but not least, in the institution of the unrestricted divine domination over the entire humankind. In "The Four Terms in the Qur'an" Mawdudi boldly states that "the term "supremacy" (al-rububiyya) is used in the Qur'an as an equivalent to the term "domination" (al-hakimiyya wa-l-malakiyya), with the Quranic description of the "Master" (al-rabb) being that of the "absolute ruler" (al-hakim al-mutlaq), the king, and the uncontested overlord of all things in existence (al-Mawdudi 1971, 93). Correspondingly, the violation of rububiyya would, from Mawdudi's standpoint, equal to the ascription of associates to Allah, and, moreover, it would ultimately result in man vesting himself with the right to set his own rules of conduct.

As contrasted to rububiyya, the purpose of the term ilah is to reflect the passive aspect of the divinity of Allah (uluhiyya), namely the fact that it is only Allah to whom, as the sole object of worship ( $m a^{c} b u d$ ), the attributes of divinity are allotted. Once again, it is the idea of Allah's absolute authority over the entire mankind that appears to be at the core of Mawdudi's understanding of uluhiyya. "The essence of uluhiyya is, generally speaking, authority (al-sulta) accepted by the mankind either in view of the fact that it preserves the laws of nature, or because its dictates hold sway over a man in his earthly life" (alMawdudi 1971, 23). According to Mawdudi, "the meaning of ilah is the object of worship ( $\left.m a^{\prime} b u d\right)$, and this object of worship is worth worshipping (al-ibada); this worship doesn't only comprise customs and rituals - the entire life the worshipper ('abd, lit. "slave") leads is nothing but "slavery" ("ubudiyya) and worship" (al-Mawdudi 1967, 12). This true worship of Allah is directly set off against the false worship of that which is known as "the idol" (taghut) in the traditional Quranic phraseology. "In the sense in which it is used in the Quran, it [i.e. the term taghut. $-P$. V.] denotes a person who transgresses the limits prescribed by his status as a creation of God, who sets himself up as a god and makes the people treat him as such" (Maududi 1955, 2). Taghut represents the extreme form of disobedience to divine authority: "not only does he rebel against God, denying Him and His right to lay down the law for man, but also begins to make his own law to prevail in the land" (Maududi 1955, 2), making his personality a focal point for numerous other forms of resistance to divine authority, such as lechery (fisq) and $k u f r^{2}$. In short, in Mawdudi's

${ }^{1}$ In Islamic theology and law, tawhid refers to the notion of the oneness of God, as opposed to different kinds of polytheism (shirk).

2 According to the English researcher F.Grare, for Mawdudi, "to acknowledge any other entity [besides Allah. - P. V.] as being sovereign or to accept any principle of authority is equivalent to idolatry" (Grare 2011, 166). 
opinion, to worship taghut is to be under the sway of everything this term denotes, including "any state, any power and any leadership willing to encroach upon Allah, to rebel against him and to impose its authority in lieu of the authority of Allah" (al-Mawdudi 1971, 101).

Of all the four terms that serve as the basis for Mawdudi's ideological system, din, viewed as the "all-embracing way of comprehension and action in the life of man" (alMawdudi 1988, 13), is probably the most complex and sophisticated one. As J.-P.Hartung justly points out, "the Qur'anic term 'din' constitutes the glue which ties Mawdudi's other three fundamental Qur'anic terms together. It justifies 'ibada out of the acknowledgment of God's ultimate authority as rabb and ilah" (Hartung 2014, 96). In the eyes of Mawdudi, the aim of din is to point to the universal "system of life" which man is free to choose for himself voluntarily in accordance with the Qur'anic concept of free will. Mawdudi defines din as "the law" (al-qanun), "the resolutions" (al-hudud), and "the way" (al-shar' wa-ltariqa) that jointly make up "the philosophical and practical system the man is guided by" (al-Mawdudi 1971, 125). Despite the fact that man is free to choose between all the existing "systems of life", it is only the religion of Allah (din allah) that fully corresponds to the laws of nature by virtue of its being based on the principles of the "political system" of Islam. Nature appears to be the boundary line drawn between Islam on the one hand and jahiliyya ${ }^{3}$ and shirk on the other. "As for the non-din systems, the ones based on submission to authority (al-sulta) other than Allah, He rejects them, and it is not natural that He should like them" (al-Mawdudi 1971, 129). In the words of Mawdudi, "if the authority owes itself to the commandments of a monarch, then the person concerned is in the monarch's din (fi din al-malik), if some sheikhs or priests prescribe it, then he follows their $\operatorname{din} . .$. Long story short, the decisive factor as to the din the person follows is he whose orders he deems utmost and whose judgments - final" (al-Mawdudi 1971, 125). Din ultimately acquires the status of a universal, all-around "system of life" in its ideological, philosophical, moral and practical dimensions (Qadi 1987, 152), making Mawdudi conclude that it approximates the notion of "state" in the Western European legal-political discourse (Jackson 2011, 128). "There is perhaps no term in any language of the world which would be of such a universal comprehensiveness as to fully embrace the notion of a din. The word "state" does, to some extent, approximate to the sense, but even this word is to be substantially extended in terms of its meaning in order to embrace the notion of din" (al-Mawdudi 1971, 127).

It appears that, in defining din, Mawdudi was influenced to no small degree by the views on the interrelation between religion, Shariah and nature expounded by Qutb alDin Ahmad Dihlawi (1703-1762), an Indian faqih better known as Shah Wali Allah of Delhi, in his treatise entitled "The Conclusive Argument from Allah". As R. Jackson observes, Shah Wali Allah "developed a theory of the relationship between revelation and its socio-historical context by arguing that the ideal form of din (which he interprets to mean primordial ideal religion) is synonymous with the ideal form of nature" (Jackson 2011, 115). Shah Wali Allah believed that notions of genuine, natural religion (din) had been historically actualized through the succession of divine revelations presented to the

${ }^{3}$ In the historic Islamic literature, jahiliyya denotes the totality of various customs and rules of conduct peculiar to the pagan tribes of Arabia before the advent of Islam. As for Mawdudi, he utilizes the term in his writings to refer to the political dimension of polytheism, which manifests itself in the shape of various un-Islamic ideologies, forms of government and political regimes 
mankind depending on its prevailing socio-political conditions. Although inalterable and universal in its essence, din tended to take the shape of specific legal and religious injunctions, known as Shariah, in conformity with the customs and everyday practices of the society the divine revelation was about to be sent down to. "And know that the legal provisions (shara' $i$ ) of the prophets, peace be upon them, differed for [known] reasons and for the good of mankind, namely because the signs of Allah (sha'a'ir) had been given only to those ready to accept them, as well as because, in order to decide the fate of the mankind, multiple customs and conditions had to be taken into consideration" (Dihlawi 1933, 89).

Both the active (rububiyya) and the passive (uluhiyya) aspects of Allah's divinity manifest themselves through the so-called "divine domination" (hakimiyya) over the human world. This domination essentially amounts to an unlimited divine authority over the humankind and constitutes what can be termed Allah's legal right to legislature as opposed to the unconditional obedience to his authority and ordinances (ubudiyya) man is expected to show. From Mawdudi's perspective "in Islam, it is Allah to whom alone hakimiyya belongs. The Qur'an accurately clarifies the ideology of tawhid by pointing to the fact that it is only Allah who has no associates not only in terms of religion but also from the political and legal standpoint... Verily, with regard to Islamic ideology, it is Allah the Almighty alone who himself (bi-thatihi wa aslihi) is the ruler. As for any other authority, it is deemed shared and prohibited" (al-Mawdudi 1980, 81-82). Mawdudi believes that "the foundation of the entire political theory of Islam rests upon the idea that both the executive and legislative powers should be snatched out of people's hands at individual and collective levels so that no man could neither exercise his authority (an yunaffitha amrahu) over other men, nor legislate for them. Verily this [right] belongs to Allah alone, and there are no associates to him in exercising it" (al-Mawdudi 1967, 27).

It is possible to conditionally classify the "divine domination" into the absolute, or legal, domination (hakimiyya qanuniyya), and the factual, or political, domination (hakimiyya siyasiyya). Speaking on the essence of the "legal domination", Mawdudi pointed out that the expression was commonly used to denote Allah's supreme legislative authority. To reject this authority meant, in his eyes, to openly admit to being infidel ( $k u f r)$. "Islam has decided the issue of the legal domination by vesting the right to dominate exclusively in Allah the Almighty, whose factual domination is the sole basis of this Universe, and to whom belongs the uncontestable right to dominate over the entire mankind... This is what has been clarified by the Qur'anic formula... "judgment belongs to Allah alone"... From the Qur'anic standpoint, it is outright kufr to deny him his right to dominate: "And whoso judges not by that which Allah has sent down, these it is who are the disbelievers" (al-Mawdudi 1981, 23). On another occasion, Mawdudi stated as follows: "The Holy Qur'an has made it incumbent upon the mankind to obey Allah sincerely and to observe the laws given by Him alone, while at the same time man has been prohibited from disregarding His laws in favor of other laws, as well as of his own laws and whims" (al-Mawdudi 1978, 13).

Apparently, it was Mawdudi's rendition of the Qur'anic term rabb and its derivative rububiyya that predominantly determined his view of Allah as the subject of "legal domination". Since the only creator of the world was rabb, Mawdudi used rabb and hakim as interchangeable terms, applying the latter to the subject of hakimiyya. Still Mawdudi was clearly aware of the fact that it was impossible to identify rububiyya with hakimiyya fully, and that is what eventually made him regard rububiyya as the substantive element of Al- 
lah's being, as opposed to hakimiyya, which, according to him, had to be looked upon as the manifestation of rububiyya in the physical world. "For Mawdudi, the prime function of the Creator, after calling the universe into being, was to issue rules and regulations for its functioning so that sovereignty thus became largely identical with legislative force, which is why Mawdudi spoke of God's sovereignty as "legal sovereignty" (Hartung $2014,102)$. Yet, since din was, in Mawdudi's view, a "system of life" one was free to choose without any compulsion, there was no reason to treat "legal domination" as absolute and unconditional.

As in "legal domination", "political domination", which Mawdudi defines as "the control over political power established in order for the "legal domination" to take its [due] place" (al-Mawdudi 1981, 19), is the prerogative reserved exclusively to Allah, but, unlike "legal domination", it is supposed to operate directly in the physical world by means of the so-called "agency" (wikala), or rather "divine deputyship" (caliphate). "In the language of politics and law, there is no way to say that any one agency with ambitions to execute $h a-$ kimiyya by making use of political force is the true subject of domination; it is evident that no such agency could be the bearer of hakimiyya since it is not entitled to legal domination. Its authority is circumscribed by the law it has no power to alter...Therefore, we can see that the Qur'an applies the term "caliphate" to describe this force, that is to say, neither this force nor this authority exercise supreme rule, for they are nothing but the deputy of the supreme ruler - Allah the Mighty and Majestic" (al-Mawdudi 1981, 24).

The concept of hakimiyya is undoubtedly the cornerstone of Mawdudi's entire legal political theory. In the apt expression of Muhammad 'Imara, "hakimiyya serves as the key to understanding Mawdudi. We will not be able to appreciate the "novelty" of his ideas as against the ideas of his predecessors from among the leading figures of the Islamic awakening unless we fully grasp his concept of hakimiyya" ('Imara 2011, 130). From the beginning the concept has been met with mixed feelings on the part of various Islamic political thinkers, remaining a matter of intensive scientific debates to this very day.

In 1963, Wahid al-Din Khan (b. 1925), a renowned Indian faqih, published his book "Error in Interpretation", in which he subjected the theological foundations of hakimiyya to sharp criticism. According to the Canadian researcher 'Asif Iftikar, "Khan's book represents one of the first comprehensive and serious intellectual challenges to Mawdudi's religious thought and is especially important as it comes from within the ranks of Jama'at-i Islami" (Iftikar 2004, 29). As the scholar notes, Wahid al-Din Khan believed that Mawdudi had dramatically departed from the traditional interpretation of the "four terms", especially the term din, which he completely redefined in order to lay the foundation of his overall concept of religion and state (Iftikar 2004, 29). From Wahid al-Din Khan's perspective, despite the fact that $d i n$ was indeed the pivotal concept of Islam, it was nevertheless wrong to claim that it could be used to denote the Islamic "way of life" in its political and legal dimensions since the concept was utilized in the Quran solely to reflect the spiritual bond between man and Allah. "Being a means for us to understand all the aspects of [Islamic] religion in keeping with the overall Islamic history, the true concept of din signifies, in its fundamental essence, the establishment of a kind of relationship between man and Allah that is based on fear, love and hope, with worship ('ibada) being an essential manifestation of this relationship. It is thus inevitable that, when this kind of relationship is truly established, man becomes obedient to the commandments of Allah, avoiding that which is forbidden to him and making his desires conditional on the desires of Allah" (Khan 1992, 
131). Naturally, it follows from Wahid al-Din Khan's reading of din that there is no way to identify the concept with the idea of the Islamic state and the notion of "political domination" it is supposed to be based on. "Din stands for "servility in the face of Allah" in the most general sense of the term; everything else is nothing but inner manifestations of this servility and meaning thereof. Din has nothing to do with the notion of "system" (nizam) some people have tried to make use of in order to bring together different theoretical and practical aspects of [the Islamic] religion" (Khan 1992, 131).

Another authoritative scholar to raise objections against the concept of hakimiyya was Abul Hasan Nadwi, who, like Wahid al-Din Khan before him, maintained that Mawdudi's political reading of the "four Qur'anic terms" ignored the moral and ethical sides to Islamic religion, reducing it to mere political ideology whose sole aim was to seize political power and to build the Islamic state. According to Abul Hasan Nadwi, to such an extent was Mawdudi's mind dimmed by the prevailing terminology peculiar to political science (such as "democracy", "revolution", and, especially, "system") that he made it the basis for his religious, political doctrine, disregarding the fact that the terms in question were overwhelmingly the product of Western European political practice, their specific meanings conditioned by the features of different historical and cultural environments (Nadwi 1979, 39-41). "One difference between the followers of those who are trying for the revival of Muslims and Islam (through the modernist-Islamist interpretation) and those reformists and renewalists who have had a dini and imani training is clear: while the aim of the first group is the control of political power, establishment of Islamic state and the organization of human life, the objective of the latter is winning the benevolence of God, success in the Hereafter, commitment to faith and following the sira of the Prophet" (Zawahir 2008, 81). Moreover, Abul Hasan Nadwi appears to be highly skeptical of Mawdudis assertion that to deny din in its particular legal-political dimension is, in fact, to ascribe associates to Allah (shirk), embodied by the "idols" (tawaghit) of un-Islamic statehood, Western political ideologies, and secular culture. "There are, undoubtedly, varied presentments of pagan ignorance as, for example, obedience to the powers defying God, or acknowledgement of the authority, directives, and laws of an un-godly regime; but these evince merely subservience to the values, principles, and spirit of idolatry, and cannot be equated with the stark infidelity displayed in adoring idols or deifying beings other than God. For all these acts occupy a secondary place to the matrix of paganism, it would be improper to strike a balance between the substance and the accidents, the essential and the accessories" (Nadwi 1979, 55).

Against the background of the entire Islamic scientific community, it is Hasan alHudaybi (1891-1979), the second General Guide (murshid 'amm) of the "Society of Muslim Brothers", who stands out as one of the most implacable opponents of Mawdudi. His objections to the theory of hakimiyya have been set forth in his book entitled "Preachers not Judges" (Du'at la Qudat). In the words of B.Zollner, "by no means does Du'at la Qudat question the idea of God's oneness (tawhid) and its inference that he is the originator of just and divine rule. Yet, al-Hudaybi abandons the radical position. He sees this interpretation [i.e. the doctrine of hakimiyya. $-P$. V.] as an undifferentiated, reductionist understanding of God's authority..." (Zollner 2009, 150). Hasan al-Hudaybi essentially denies hakimiyya its right to exist (Sattar 1995,15) by claiming that the expression is unknown to either the Qur'an or sunna. "It is our strong conviction that there is no aya that implies the existence of hakimiyya; after having resorted to deep inquiry into the reliable 
(sahih) ahadith of the Prophet, peace be upon him, we failed to spot a single hadith dealing with this expression" (al-Hudaybi 1977, 75). Apparently, from the viewpoint of Hasan al-Hudaybi, Mawdudi's theory revolved around the belief that if a man was to promulgate laws on his own, his attempts at legislation would be nothing but encroachment on "Allah's domination". As a response to this tentative theory, al-Hudaybi resolved to promote a wider freedom of self-determination as regards legal issues, with his main proposal being to differentiate between the unalterable, eternally valid rules of divine law ('ibadat) and the variable rules of practice. According to al-Hudaybi, the rules of 'ibadat make up the Shari'ah rules found in the Qur'an and sunna. These rules are never subject to change in the course of time; hence, they constitute the invariable component of Islamic law. As for the other category of rules, which he calls mubahat ("permissible actions"), it is composed of changeable laws (Zollner 2009, 151). Although the rules of mubahat may be formulated on the basis of the secondary "rational" sources of Islamic law, such as $i j m a^{4}$ or qiyas ${ }^{5}$, it is a must that they correspond to the provisions of the Qur'an and sunna. The Islamic law should not be regarded as a set of irrevocable normative rules laid down once and for all, which was, from al-Hudaybi's standpoint, the main idea behind Mawdudi's concept of hakimiyya, but rather it should be viewed as a system of flexible legal norms subject to changes as time and conditions vary.

The principal objections raised by al-Hudaybi against the theory of hakimiyya appear somewhat unfounded as he seems to have failed to differentiate between the "legal domination" and the "political domination". Contrary to his assertions, there are no indications that Mawdudi ruled out the possibility of legislating independently on issues unresolved by the existing rules of Shari'ah. Moreover, it was his tendency to widen the scope of the lawmaker's discretion as much as possible, which is evident from his seemingly broad interpretation of the concept of $i j t i h a d$. "Islam does not totally exclude human legislation. It only limits its scope and guides it on right lines. The human legislation, according to Islam, is and should be subject to the Supremacy of Divine Law and within limits prescribed by it" (Maududi 1960a, 74).

Certain modern researchers have expressed opinions as regards the concept of hakimiyya that seem to be more grounded. According to these scholars, hukm (lit. Ar. "authority", "decision", "legal rule", "legal injunction"), which is the root term for hakimiyya, has never served to denote neither any legal political phenomena nor any kind of political authority. In the words of the Egyptian scholar Muhammad Sayyid al-Ashmawi, "the word hukm, in the sense in which it is utilized in the Holy Quran, is quite different from what it has come to mean in the modern [Arabic] language...As a Quranic term, hukm linguistically and lexically designates the trial and the settlement of disputes, while it is also possible to translate the word as prudence and wisdom. As for the political authority, or, to use modern parlance, "government" (al-hukuma), the appropriate Qur'anic word would be "order" (al-amr), which is the reason the "ruler" (al-amir), i.e. he who is empowered to give orders, is called the way he is" (al-Ashmawi 1996, 57-58). Al-Ashmawi's view of hukm is shared by Muhammad 'Imara who is known for rebuking sharply those Muslims who, as he claims in his book "The Islamic State between Secularism and Religious Authority", "have derived [the term] hakimiyya of Allah, all praise be to Him, from

${ }^{4} \mathrm{Ijma}^{\text {c }}$ is a legal term referring to the consensus of the most authoritative Muslim scholars on a particular juridical or legal issue.

${ }^{5}$ Qiyas, or analogical reasoning, constitutes one of the secondary "rational" sources of Islamic law. 
the term hukm, for they believed it to have been used in the Qur'an, and, consequently, by the Islamic political thought in general, to indicate political regime and supreme political authority, while in fact in most cases the word in question would be used in the Qur'an to denote either "trial" or the "settlement of disputes" (Imara 1988, 35). Hence, according to Muhammad 'Imara, "hakimiyya has nothing to do with neither caliphate, nor imamate, nor what we would call the form of government in our modern political literature" ('Imara 1988, 35).

Among the scholars who reject the political aspect of hakimiyya are those who perceive the concept as a reflection of the Khawarij ${ }^{6}$ doctrines. For example, the Lebanese legal scholar Haydar Ibrahim 'Ali has alleged that Mawdudi was "the first among those working on the theory of hakimiyya in the modern age, that is, after the time the Khawarij advanced their famous slogan...that read: "judgment belongs to Allah alone". Despite the fact that the scope of the slogan has been limited in its historical context by certain aims and events...its meaning has currently exceeded the limits of the historical court of arbitration, to the point that at present it has come to denote authority and domination in full" ('Ali 2001, 133). Of similar opinion is Muhammad al-Shafi'i, an Egyptian researcher, who believes that "Mawdudi has borrowed the idea of hakimiyya from the Khawarij, according to whom it is only Allah who is the creator of the Universe and the supreme ruler to whom alone belongs the absolute supreme authority. As concerns a man, he is just a deputy (khalifa) of this ruler...tasked with overseeing the application of his laws and executing government policies along the lines of his commandments" (al-Shafi'i 1999, 66).

The proponents of the "neo-Khawarij" theory have come under criticism from the likes of the Egyptian scholar Nasr Hamid Abu Zayd, who is of the opinion that the historical origins of hakimiyya ought to be traced back to the political manipulations Muawiya b. Abu Sufyan, the governor of Syria, resorted to in order to secure victory over his adversaries at the battle of Siffin, with his ultimate aim being to transform the Syrian viceregency into a full-blown independent statehood. "The ideological aspect behind the whole arbitration trick becomes clearly visible as soon as we realize that it was used to move the struggle away from the prevailing socio-political realm to the realm of religion and nass... The recourse to nass within the framework of the socio-political struggle has resulted in its validity becoming "universal", with this "universality" reaching the peak of its hegemony in the latest religious philosophy, as [the example of] hakimiyya suggests" (Abu Zayd 1994, 102).

To top it all, Muhammad Sayyid al-'Ashmawi, whom we have cited earlier, has denied altogether the very Islamic nature of the concept of hakimiyya. Al-Ashmawi traces the emergence of the notion of hakimiyya in modern political thought to the influence of Judaism and the ideology of Talmud, which he vaguely defines as legal and political "Israelisms" (isra'iliyyat). "They say that to fulfil the orders of Allah and to execute His hakimiyya is to judge by that which He has sent down, as well as to acknowledge that it is only He who is entitled to legislate and to try. I believe that this view... has been heavily influenced by the Judaic thought or, more precisely, by what is known in the Islamic thought as "Israelisms", i.e. multiple Jewish ideas that have managed to infiltrate Islam

6 The Khawarij (lit. Ar. "those who seceded") were members of a group of early Muslims who opposed the arbitration between the fourth "rightly-guided" caliph 'Ali b. Abu Talib (599-661) and the governor of Syria Muawiya b. Abu Sufyan (603-680) at the battle of Siffin (657 AD). This group is considered the first to ever advance the slogan "judgment belongs to Allah alone". 
despite being completely alien to it" (al-Ashmawi 1996, 53). Al-Ashmawi is of opinion that, unlike the Pentateuch, which is essentially a product of systematization of the Judaic legal-religious rules, the Quranic revelation is largely composed of moral-religious injunctions, with the portion of legal rules proper being scarce to the extent that it is only with considerable reservation that the very term "law" could be applied to it. Hence, from al-Ashmawi's standpoint, "the fusion of the two messages (i.e. Judaism and Islam - P. V.), with Islam following in the footsteps of Judaism, alters the very foundation of Islam and its central axis, distorting its purport and forcing it to take the shape of "Israelism", and ultimately of Judaism" (al-'Ashmawi 1996, 55).

Yet, there are some modern researchers who concede to the possibility that hukm could be used in the Qur'an as the term denoting supreme political authority. Foremost among these scholars is the Egyptian Hisham Ahmad Ja'far, who has opined that the term could assume political connotations in the Qur'anic phraseology. "Some have denied that hukm is used in the Qur'an and sunna as a political term, claiming that it only implies trial proceedings (al-qada') and the settlement of disputes, as well as knowledge and wisdom. These [scholars] seem completely oblivious to the fact that for the trial to take place, it is necessary that the court ruling $(a l-h u k m)$ be political in its character, for it is the political authority alone that is entitled to enforce court decisions on the parties to a dispute" (Ja'far 1995, 63). Of similar opinion is another Egyptian scholar, Mahmud 'Akasha, who believes that the concept of hakimiyya has nothing to do with the political thought of the Khawarij. "Hakimiyya has not originated from the hukm of the Khawarij and the slogans they advanced, such as "judgment belongs to Allah alone", or "it is only Allah who passes judgments", for what a difference there is between the legal dimensions of hakimiyya and the Khawarij arbitration! From the perspective of the Khawarij, hukm basically stands for trials and the settlement of disputes, while, according to the scholars of usul al-figh, the term merely indicates that Allah is the only ruler" ('Akasha 2002, 234).

3. Conclusion. It should be clear from the foregoing discussion that the genesis of the concept of hakimiyya in the writings of Mawdudi has essentially paved the way for the emergence of all the other major trends and tendencies in his subsequent legal-political thinking. For instance, as a legal concept, hakimiyya lies at the core of Mawdudi's theory of the Islamic state. One major trait of this theory is that it fails to acknowledge caliphate as a medieval form of monarchical rule, or, to use Mawdudi's terminology, "the caliphate of the messenger of Allah", but rather sees it as a valid, imperative notion of "divine deputyship", that is to say, as an ontological opposite to the very idea of monarchy - the so-called "caliphate of Allah". The doctrine of "divine domination" has played a significant part in the development of the specifically Mawdudian theory of sources of Islamic law (usul alfiqh) as it has been employed to substantiate his refusal to acknowledge the Islamic nature of the Muslim "man-made laws". On top of that, by equating din to the ultimate Islamic statehood, it has become feasible for Mawdudi to make hakimiyya the basis for his theory of the "renewal of faith" (tajdid al-din) and the concept of "Islamic revolution". At present, despite being heavily criticized on the part of the Islamic academic community, the doctrine of hakimiyya remains the mainstay among the adherents of a number of Islamic political movements that harbor extremist leanings. It is thus possible to conclude that the concept of hakimiyya should be counted among the most important doctrinal innovations the Islamic legal-political thought owes to Mawdudi. 


\section{References}

Abu, Zayd, Nasr, Hamid. 1994. Naqd al-khitab al-dini [A Critical Inquiry into the Religious Speech]. Cairo: "Sina". (In Arabic)

'Ali, Haydar Ibrahim. 2001. al-Tayyarat al-islamiyya wa qadiyya al-dimuqratiyya [The Islamic Currents and the Problem of Democracy]. Beirut: "Markaz Dirasat al-Wahda al-Islamiyya". (In Arabic)

al-Ashmawi, Muhammad Sayyid. 1996. al-Islam al-siyasi [Political Islam]. Cairo: "Maktabat al-Madbuli alSaghir". (In Arabic)

'Akasha, Mahmud. 2002. Ta'rikh al-hukm fi-l-Islam. Dirasa fi mafhum al-hukm wa tatawwurihi [The History of Hukm in Islam. A Study of the Concept of Hukm and Its Development]. Cairo: "Mu'assasa alMukhtar". (In Arabic)

al-Mawdudi, Abul A'la. 1988. al-Din al-qayyim [The True Faith]. Jeddah: "Dar al-Sa'udiyya". (In Arabic)

al-Mawdudi, Abul A'la. 1980. al-Hukuma al-islamiyya [The Islamic Government]. N. p.: "al-Mukhtar al-Islami”. (In Arabic)

al-Mawdudi, Abul A'la. 1971. al-Mustalahat al-arba'a fi-l-qur'an [Four Terms in the Qur’an]. al-Kuwait: “Dar al-Qalam". (In Arabic)

al-Mawdudi, Abul Ála.1978. al-Khilafa wa-l-mulk [Caliphate and Kingship]. al-Kuwait: "Dar al-Qalam”. (In Arabic)

al-Mawdudi, Abul A'la. 1967. Nazariyya al-islam al-siyasiyya [The Political Theory of Islam]. N.p.: "Dar alFikr".(In Arabic)

al-Mawdudi, Abul A'la. 1981. Tadwin al-dastur al-islami [An Outline of the Islamic Constitution]. Beirut: "Mu'assasa al-Risala". (In Arabic)

al-Hudaybi, Hasan. 1977. Du'at la Qudat [Missionaries, Not Judges]. Cairo: "Dar al-Tawzi' wa-l-Nashr alIslamiyya". (In Arabic)

al-Shafi'i, Muhammad.1999. Sultat al-dawla bayna-l-fikr al-dasturi wa-l-fikr al-islami wa fikr al-jama'at al-islamiyya (dirasa muqarana) [The Powers of State between the Constitutional Thought, the Islamic Thought and the Thought of the Islamic Groups (Comparative Study]. Cairo: "Markaz al-Mahrusa". Vol.2. (In Arabic)

Dihlawi, Shah Wali Allah. 1933. Hujjat allah al-baligha [The Conclusive Argument from Allah]. Cairo: "Idarat al-Taba'at al-Munayriyya". Vol. 1. (In Arabic)

Grare, Frederic. 2011. Pakistan's Pursuit of Democracy. Pakistan: From the Rhetoric of Democracy to the Rise of Militancy. New York; New Delhi: Routledge Press.

Hartung, Jan-Peter. 2014. A System of Life. Mawdudi and the Ideologisation of Islam. Oxford: Oxford University Press.

Iftikar, 'Asif. 2004. Jihad and the Establishment of Islamic Global Order: A Comparative Study of the Worldviews and Interpretative Approaches of Abu al-A'la Mawdudi and Javed Ahmad Ghamidi. Master of Arts Thesis. Montreal: McGill University.

'Imara, Muhammad. 2011. Abu-l-a'la al-mawdudi wa-l-sahwa al-islamiyya [Abul A'la al-Mawdudi and the Islamic Awakening]. Cairo: "Dar al-Salam". (In Arabic)

'Imara, Muhammad. 1988. al-Dawla al-islamiyya bayna-l-'́lmaniyya wa-l-sulta al-diniyya [The Islamic State between Secularism and the Religious Authority]. Cairo: "Dar al-Shuruq". (In Arabic)

Jafar, Hisham Ahmad. 1995. al-Abad al-siyasiyya li mafhum al-hakimiyya. Ru'ya márifiyya [The Political Coordinates of the Concept of Hakimiyya: An Epistemological View]. Herndon: "al-Ma'had al-Alami li-l-Fikr al-Islami”. (In Arabic)

Jackson, Roy. 2011. Mawlana Mawdudi and Political Islam. Authority and the Islamic State. London; New York: Routledge Press.

Khan, Wahid al-Din. 1992. Khata' fi-l-tafsir [The Error of Interpretation]. Cairo: "al-Risala li-1-I'lam al-Duwali". (In Arabic)

Maududi, Sayyid Abul A'la. 1955. Four Basic Quranic Terms. Lahore: Islamic Publications (Pvt) Limited.

Maududi, Sayyid Abul A'la. 1960 (a). The Islamic Law and Constitution. Lahore: Islamic Publications (Pvt.) Ltd.

Maududi, Sayyid Abul A'la. 1960 (b). Towards Understanding Islam. Lahore: Idara Tarjuman-Ul-Quran (Pvt.) Ltd.

Mawdudi, Sayyid Abul A'la. 1988. Towards Understanding the Quran. Abridged Version of Tafhim al-Quran. London: The Islamic Foundation. Vol. 1.

Nadwi, Sayyid Abul Hasan Ali. 1979. Islamic Concept of Prophethood. Nadwa, Lucknow: The Academy of Islamic Research and Publications. 
Qadi, I'tidal. 1987. al-Fikr al-tarbawi 'inda-l-mawdudi [al-Mawdudi's Educational Thought]. Mecca: "Jami'at Umm al-Qura". (In Arabic)

Sattar, Noman. 1995. "Al Ikhwan Al Muslimin" [Society of Muslim Brotherhood]. Aims and Ideology. Role and Impact". Pakistan Horizon, vol. 8, no. 2, pp. 7-30.

Zawahir, Nafeel M. 2008. "Comparative Study on Abul Hasan Nadwi's Political Thought with Practical Reference to His Contemporaries: Abul A'la Mawdudi and Sayyid Qutb". PhD diss., University of Wales.

Zollner, Barbara. 2009. The Muslim Brotherhood. Hasan al-Hudaybi and Ideology. London: Routledge Press.

Received: 20.02 .2018

Accepted: 04.04.2018

Author's information:

Valerii V. Pugachev - Master in Law; seselj@bk.ru 